\title{
Taxation and Government Expenditures in the Center of the Albanian Policy Debate
}

\author{
Teuta Balliu, PhD Cand. \\ Lecturer, Faculty of Economy in University of Elbasan "A.Xhuvani" \\ teuta.balliu@uniel.edu.al
}

Loreta Bebi, PhD Cand.

Lecturer, Faculty of Economy in University of Elbasan "A.Xhuvani"

loreta.bebi@yahoo.com

\begin{abstract}
There are only a very limited number of instruments at a government's disposal when it tries to stimulate long-run growth, and one of these instruments is fiscal policy. The last few years we have seen government spending, taxation, and deficit financing move to the forefront of policy debates worldwide. That is why it's very important to analyze the way in which taxation and government expenditures influence economic growth. This problem is especially vital for the countries suffering very low or negative rates of growth, as Albania is. The aim of this study is to have a clear view of the fiscal reform process and economic development in Albania starting from 1991 till to present and to analyze the impacts of tax revenue and government expenditures on economic growth and development. In general a tax policy aiming at reducing the number of taxes and tax rates, expanding tax incentives to encourage investment, boost exports, encourage the development of domestic production, transfer economic structure and stabilize finance and monetary policies in accordance with the requirements of a market economy to meet the requirements of international economic integration. Tax policy has contributed to encourage investment and promote business and production. Entrepreneurs and investors considered the tax reduction rate and the increase of government expenditures extremely positive and encourage business investment decisions and expansion. Government expenditures in sectors like education, health, infrastructure, and research and development have a positive impact on economic development of a country.
\end{abstract}

Keywords: Fiscal policy, tax system, government expenditures, economic growth.

\section{Introduction}

In the economic and political science, the fiscal policy is the use of government expenditures and revenue collection in order to influence the economy. The fiscal policy can be in contrast with other leading types of macroeconomic policy, such as the monetary policy, through which efforts are made to stabilize the economy by using interest rates and expenditure control. The two main instruments of fiscal policy are government expenditures and taxes. The changes in the level and composition of taxes and government expenditures can influence economic variables such as the aggregate demand, the level of economic activity, the model of source and income distribution (Assaf Razin and Sadka Efraim , 1991). The costs and state taxes directly affect the overall economic performance as they make up the largest part of the activity of the national economy. Fiscal and monetary policies are two basic components of state economic policy which are used for macroeconomic purposes such as the influencing of the total domestic product, the employment level, the incomes and the price level. The fiscal policy is related to the government actions in changing the composition of the revenues and the public expenditures to manage aggregate demanding order to maintain sustainable economic growth with relatively high employment, without causing inflation, without increasing the public debt and with a satisfactory payment balance. Instruments of the fiscal policy can be even applied for other purposes such as the field of education policy, education, demographic, and cultural purposes, as well as construction, health and commercial purposes. The state is presented as an employer in public enterprises, public administration and the law enforcement and security bodies. Thus, for example through customs policy, the state increases exports and reduces imports, and by doing this it reduces the deficit in the employment balance and improves the value of the national currency. Fiscal policy has also got an impact on regional 
development and the improvement of the economic structure (Crawford I, M. Keen and S. Smith, 2009). State intervention in the economic performance through fiscal policy is justified by the adjustments made in terms of eliminating the phenomena which become an obstacle in maintaining the general welfare of the society. These phenomena are related to the imperfect actions of the market in: protecting the poor class of the society, creating jobs, eliminating monopolies and raising proper competition, and fairer redistributing of wealth, etc. Fiscal policy is one of the components of state economic policy which is used for macroeconomic purposes in order to influence the product, the employment and price level. Tightening fiscal policy is applied to close the gap of expansion in a way that affects the reduction of aggregate demand by cutting down public expenditures. While the recession gap is closed through the fiscal expansion by increasing public expenditures in order to influence the growth of aggregate demand. The issue of the budget deficit and its coverage are particular problems as they are directly linked with inflation as a phenomenon with negative effects on the economy, and the population saving level which is necessary for future investments.

\section{State budget}

The private sector in Albania is increasingly becoming a determining factor in distributing sources, by providing a continuous important contribution in creating GDP. However, as in all other countries with a developed market economy, a significant part of the monetary value is distributed and redistributed through the public sector. The government becomes a very important factor for the development and progress of the country if it has the appropriate legal and financial instruments to attract through a tax system, a considerable part of the private sector revenues (D.Myles, 2009). Government work analysis can be done in two plans. Firstly, we can analyze how much and when does the government provide incomes. Secondly, we can analyze the direction of the expenditures carried out by the government. The analysis of public expenditure carried out by the government is very important for several reasons (Koester B.Reinhard dhe Roger C.Kormendi, 1988). First, the economic activity of the public sector carried out by the government has a specific character and is not subject of the same rules as the economic activity of the private sector. The main principle which regulates the economic activity of the private sector is "voluntary exchange" which according to Adam Smith makes it possible for all the parts to win. Since the activity of the government is not based on voluntary exchange of the offered services, the analysis and the transparency of the expenses carried out by the government is not only a necessity but also the only way for the public to understand which are the activities and services offered and provided by the government. Secondly, it is important to do the analysis of government public expenditures in order to understand how these expenditures are financed. Theoretically public expenditures can be financed in three ways:

a. by the taxes

b. by issuing state debt titles in the form of treasure bills

c. by new money.

All these three ways have different effects on the economy of a country, and this thing makes this analysis necessary. Third, the analysis of public expenditures is a necessity in order to identify the cost of service implementation provided by the government. The cost analysis or the efficiency of the government is necessary especially during the decentralization process, where given the principle of subsidiary; the efficiency of the two governing levels is a basis criterion to decide on the distribution of functions between the local and the central authority.

Fourth, the control of budget expenditures is an important process for controlling the bureaucracy. The public sector analysis in other countries has proved that in conditions of a lack of public control over public finances, public expenditures in the contents of the administration have arisen, by reducing at the same time the amount and quality of public services intended for the public.

\section{Fiscal policy attitudes and their impact on economic growth}

The three possible attitudes of fiscal policy are the neutral, the expansionist and the contractual one (Ramsey, 1927). A neutral attitude of fiscal policy implies a balanced economy. The government expenditures are fully funded by tax general revenues and budget outcomes have a neutral effect on the level of economic activity. An expansionist attitude in fiscal 
policy includes the fact that the government expenditures exceed tax revenues. We have an expansionist fiscal policy when government expenditures are lower than tax incomes, and a fiscal expansion means tax cuts or increased public spending in order to stimulate consumption growth, i.e. growth of the aggregate demand. This happens when the government notices flounders, slow economic growth or when the unemployment is high. Thus, the growth of public spending and tax cuts leaves individuals a larger amount of money to use on consumption or investments. This thing has a direct impact on increasing employment and economic growth. While the tightening fiscal policy means cutting expenditures and increasing taxes. It is said that the government implements the tightening fiscal policy when it aims to reduce aggregate demand in order to slow economic growth or reduce inflation. Through the tightening fiscal policy money supplies decreases which further reduces costs and aggregate demand. Similarly, the reduction of money supply puts pressure or raising prices on the economy. When the government takes a decision on the fiscal policy it in advance does an evaluation of a large number of factors including the performance of variables and that of key financial and economic indicators, due to their impact on the amount of the revenues collected through taxes. These revenues are used to meet the needs of financing government programs (Szostak, 2009). Another important issue for the government is determining the budget deficit, so will the government increased or the uncovered costs covered by the loans or through money emission. The fiscal policy decisions depend largely on political considerations such as credibility and the role that government plays in the economy. It also depends on the public feedback over the direction and actions of the government. Such decisions may also be affected by external factors which means, that the government should consider the global trend of economic and fiscal policies of other countries, which may affect the reallocation of domestic companies through the benefits or the fiscal incentives. The fiscal policy measures can be directed towards facing short-term difficulties triggered by harmful flows in economy and their improvement, namely the elimination of the causes of those flows and setting the stability with the measurement of the stabilization policy (Tiebout, 1956). In addition to short-term flows, fiscal policy can even be oriented towards long-term growth of gross domestic product (GDP) respectively the incomes per resident. In this case it is about the rate of economic growth. Economic growth is measured primarily with the growth of GDP within a specified period. This increase means at the same time a rise in expenditures and public revenues, improved living conditions and raising living standards. The economic policy measures and the fiscal policy are intended to achieve an optimal rate of economic growth rather than the maximum rate. The maximum rate is achieved with full employment of all factors of production. But this would be impossible in practice. During the drafting and formulation of fiscal policy it should also be taken into account other factors such as the environmental preservation. Therefore, it is not full employment of all factors of production under ideal conditions. The optimal rate of economic growth means, use of production factors taking account other influential factors of social general interests. Since GDP grows with the increasing engagement of production factors and their best use, then among fiscal policy measures in terms of promoting economic growth can be counted those which affect the growth of labor productivity and better use of capital good, technological development and better use of production factors, such as investment incentives through tax facilitation, subsidies to various economic sectors, increased investment in infrastructure, encourage and increase investment in research, education and training , removal of excessive regulation that could hamper business expansion.

Public debates related to economic growth mainly focus on measures which encourage investments and the reduction of budget deficit in order to increase the savings of the country. They also encourage the increasing of public expenses on education, and the reformation of state regulations including regulations related to environmental protection because of the higher cost compared to the usefulness. State and other public-legal bodies possess a significant part of the national income. They appear on the demanding part in the market and they directly buy goods and pay for services they use, just like non-public entities (Boadway R., E. Chamberlain and C. Emmerson , 2009). The state uses its revenues to pay pensions, unemployment compensations, and other social assistances which are used to increase the purchasing power of those who use these payments. Thus, the state also indirectly affects to the increased demand in the market. However, demand growth is also affected by the reduction of the tax burden of taxpayers, facilities and tax exemptions. By reducing the tax burden, the purchasing power of taxpayers increases and as a result the aggregate demand increases. In terms of full employment, the growth of aggregate demand does not affect the growth of production and that of the number of employees. In this case, the increased demand would result in the increase of prices. To prevent the growth of price level the demand should decrease to the appropriate level of supply. The aggregate demand decreases with the reduction of public transfers, the reduction of public activities, the increase of tax burden and facilities' removing, and tax exemptions. All these measures taken to reduce public expenses and increase public revenues are recognized as policies' measures. If aggregate demand is less than the offer, it still comes up to the change of the price level, which means that the prices are reduced. In order to establish the balance, the state must orient fiscal policies towards the growth of aggregate demand 
by increasing expenses and reducing public revenues. Among expenditures the state increases social expenses, opens new jobs, increases investment activities and reduces the tax burden (Cremer H. and P. Pestieau, 2003). These measures affect the growth of the purchasing power of the citizens and thus also to the growth of aggregate demand and are recognized as policy measures. Whereas, in the case of neutral measures, as we mentioned above fiscal policy aims to maintain full employment and the right price level. In this case, public expenses must be allocated in a way that demand remains unchanged.

\section{Classifying budget expenditures}

The main methodological issues which are related to the analysis of budget expenditures deal with budget classification and the evaluation of budget expenditures indicators. Depending on the type and range of the analysis aimed to be realized in connection to the budgetary expenditures, these last mentioned can be classified in several ways. So budget expenditures can be classified into two groups: in expenses entirely consumed by the public administration and expenses which are reallocated by the state budget (James A. Richardson and W. Bartley James Hildreth, 1999). The first group of expenses includes expenses for staff salaries, or capital expenditures. Their nature is that they are totally consumed in the form of wages and investments by the public administration. While the second group includes expenditures such as expenses for unemployment payments or for social assistance. These expenses are not consumed by the public administration, but by certain groups of the population in need, who benefit from the reallocation of funds in their favor.

Budget expenditure can also be divided by:

- The economic classification

- The functional classification

- The institutional classification

The economic classification of budget expenditures serves to show the intended use of the revenues. As such they do not show where they are spent, but they show the economic direction of the budget expenditure, as:
a. The consumption of the public sector (in the form of staff salaries and insurances)
b. The expenditures of maintenance and subsidies
c. The capital transfers
d. The interest payments

According to the economic classification the analysis of expenditures reports serves to answer questions such as: How has the nature of public spending for the holding of public administration changed in relation to the capital investments? Are the maintenance expenditures stable? How much and how has the size of public debt affected it? What is the degree of state intervention in the economy through subsidies?

The functional classification of public expenditures aims to indicate the direction in which the public funds were spent. As such they indicate the area where public funds were spent, on:
a. Maintaining central administration
b. Protection
c. Safety and security
d. Education
e. Health
f. Housing and territorial regulation
g. Art and culture
h. Energy
i. Agriculture and forestry
j. Mines
k. Transport and communication 
The institutional classification of public expenditures groups expenditures according to their institutional destination. The budget plan sets operating costs and expenses for investments for every public institution which will be used for the realization of activities in the respective institutions.

\section{Public revenues}

The following chart reflects the Albanian GDP over the years. The Albanian rate of economic growth remains positive but it is in very low levels and far from the desired target.

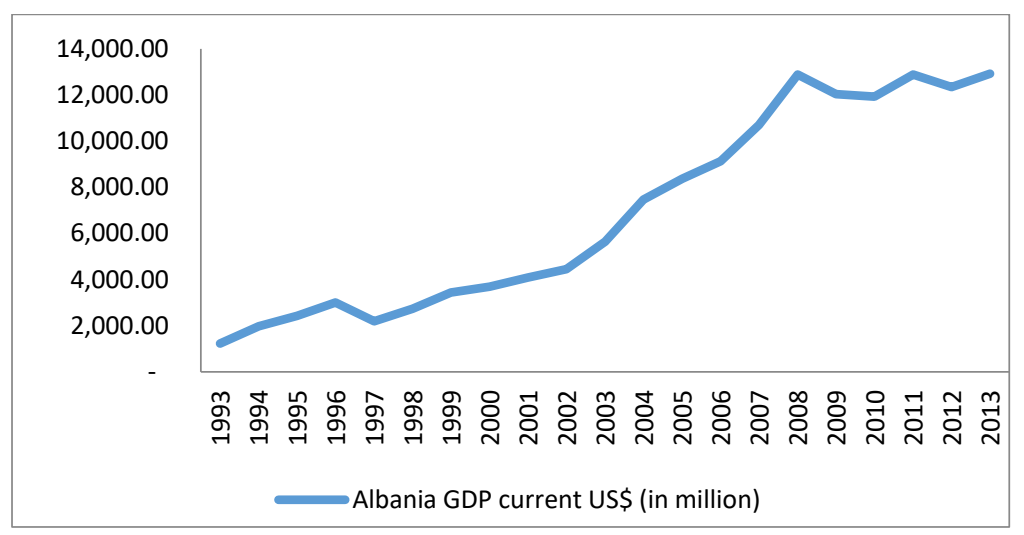

Graph 1. GDP performance

As we stated above the public debates regarding economic growth are mainly focused on measures that encourage investments, reduce the budget deficit in order to increase savings in the country, increase public spending on education, and the reformation of state regulation, including regulation regarding environmental protection due to the high cost compared to the usefulness. Graph 2 shows the data in relation to total public revenues, the total expenditures and the deficit from 1993 to 2014.

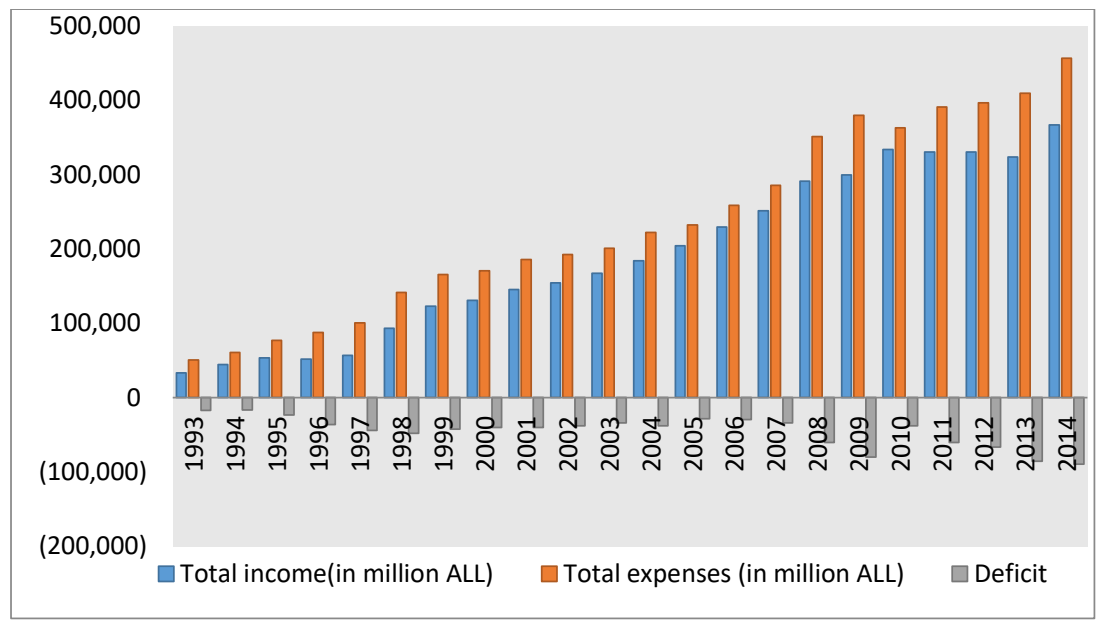


Graph 2. The performance of the total revenues, total expenditures and deficit over the years

From chart 2 and 3 appears that the level of tax revenues is almost several times higher than in 1993 . The incomes obtained from tax and customs have increased until 2006, which is almost the same with growth in two other items of income tax, but this item was the main one, about 90 percent. Although the overall tax revenues have had a growing trend over time, their growth has been sluggish.

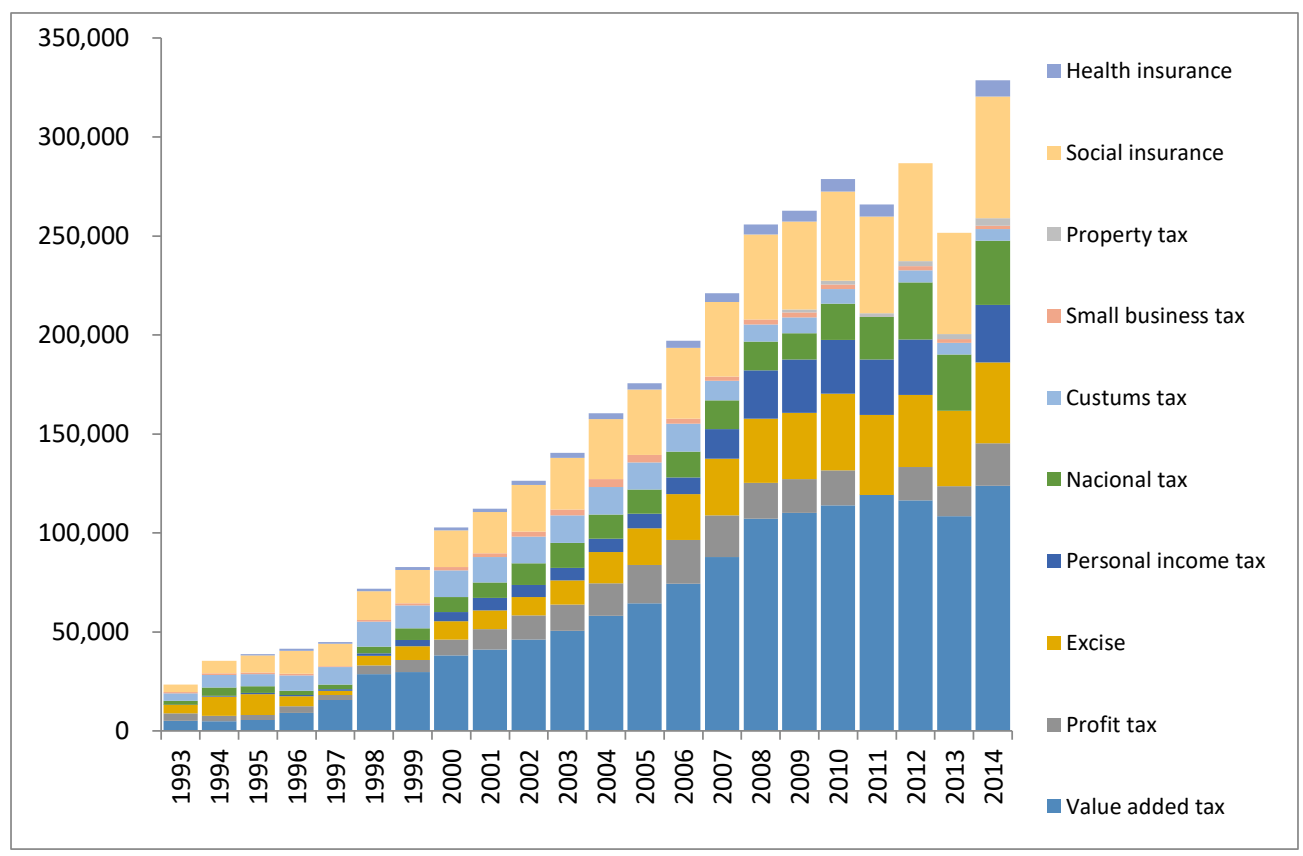

Graph 3. The performance of tax revenues (in million ALL)

An important factor of this increase may be in the tax system reforms, such as increasing the number of taxable entities, tax base increase, improvement of their management as well as the issuance of new laws and why the creation of new businesses private economic expansion is thought to be a determining factor. The structure of tax revenues in Albania is such that three major taxes provide approximately 65 percent of the total income tax to the central government. As seen in the graph 3 the main items are value added tax, excise tax and social security.

\section{Public expenditures}

One of the challenges that the fiscal policy in transition has faced, is to contribute to stabilization, but without hindering the necessary fiscal restructuring since stabilization itself requires improved fiscal instruments. Fiscal consolidation through the establishment of a balance between reducing the deficit and public debt and the need to carry out necessary capital investments, has positively affected both in terms of stability and in terms of economic growth (Prammer, 2011). According to theoretical concepts a way to see the performance of public sector expenditure is through performance. General budget expenditures at the end of 2013, amounted to about 394 billion, from 409.4 billion projected in the budget approved for this year. In this context, at the end of 2013, the fiscal deficit reached at -63.9 billion, 19.6 billion less than planned while in 2014 the deficit reached the value of 89 billion. Since the high levels of the expenditures in 1992 their trend has been falling in relation to GDP. Some of the policies of the government that have contributed in reducing government expenditures, have been cuts in public administration, in order to improve public services, the liberalization of exchange rates and prices which affected the reduction of subsidies in the economy, lowering the cost of protection, reduction of interest rates for debt payments as well as a reduction rate of the treasury bonds to internal financing. This downward trend was broken after the 
crisis in 1997 and for the following two years, considering reforms to emerge from the crisis as well as the support that was given to the Kosovo war in 1999. Since 1999 the costs have had a stable decrease which reached the lowest level in 2003, about $28.4 \%$ of the GDP. Even in the following years the level of expenditure has remained at a constant value from 28 to $29 \%$ of GDP. In 2008, the expenditures increased by about 15 percent compared with a year ago, reaching the value of 33.4 percent, the highest value since 1999. In fact it is worth mentioning the fact that there is a right link between increased government expenditures and electoral periods. This explains the high levels of spending for 2009 by even adding the effects of the crisis.

The performance of budget expenditures in an absolute amount is shown in Graph 2, while slightly below (Graph 4) reflects the budgetary costs and the pace of their growth during January-December, in the past ten years.

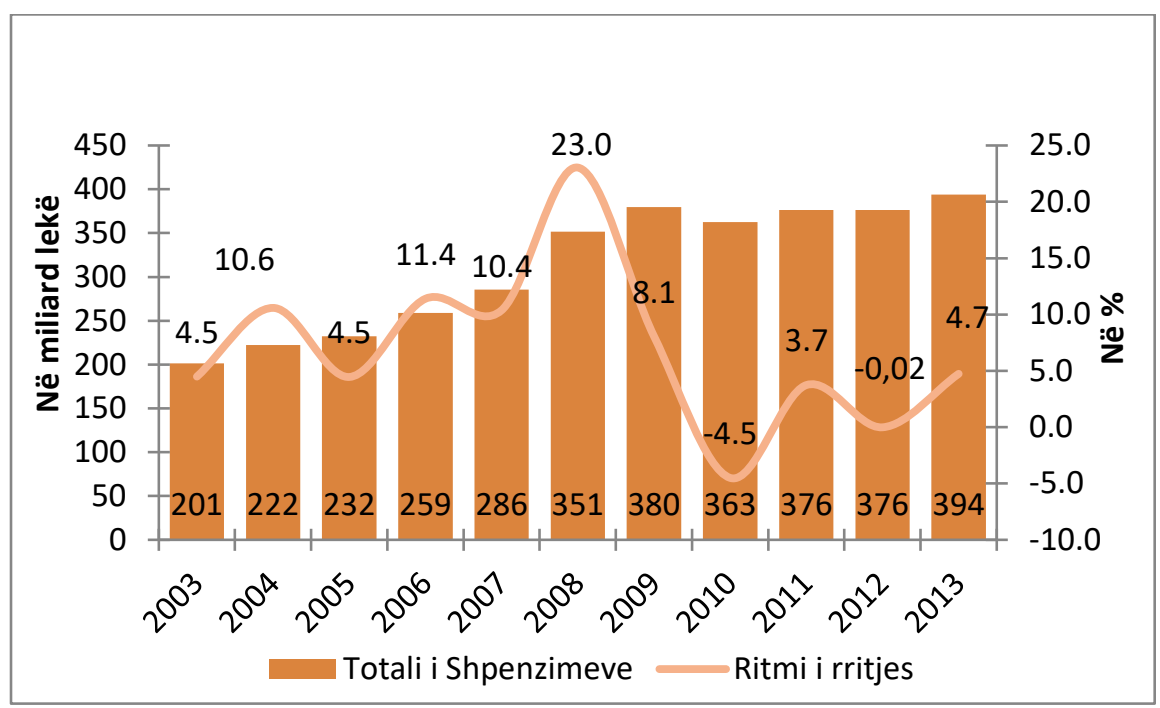

Graph 4. General expenditures and their growth rate (in Milliard ALL)

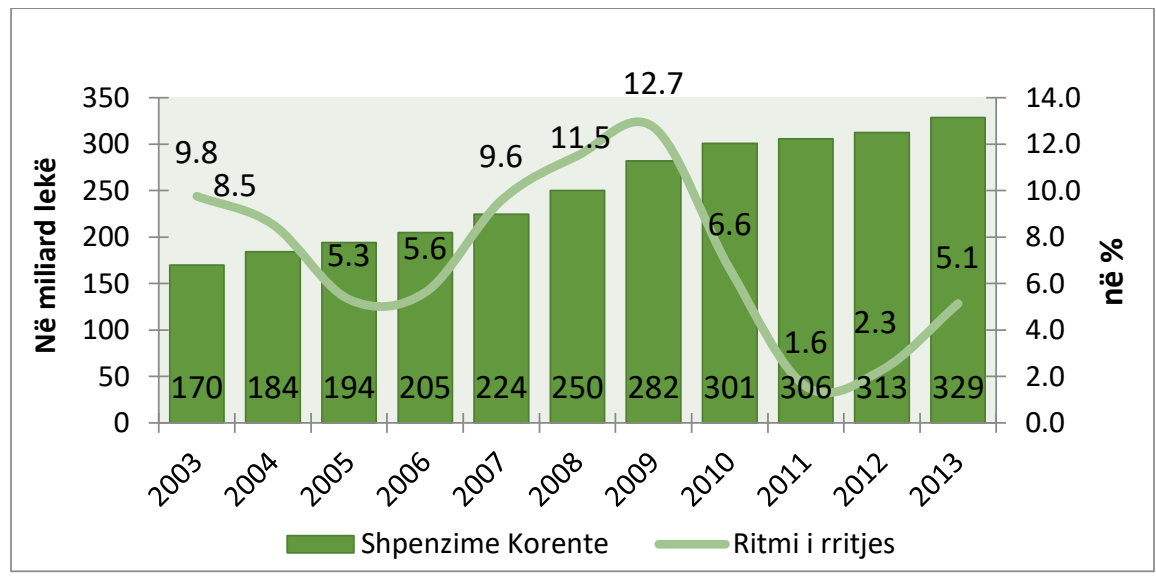

Graph 5. Current expenditures and their growth rate (in Milliard ALL) 
Graphs 4, 5, 6 and 7 make a description of the performance of general, current, and capital expenditures and investments. The big difference of current and capital expenditure makes us think that the bulk of these costs go to investments which are not very productive. Nearly half of current expenditure goes to personnel costs such as wages and contributions of social and health security. If we refer to the fiscal indicators of the state budget over the years we have found a positive feature in favor of the expenditure performance. There is a downward trend of operating costs and capital expenditures versus personnel and especially towards investments. This means that the contribution of expenditure on economic growth has been improving. This has been the goal of the expenditure policy, which has been pronounced even more these past 5 years: to reduce current expenses by reducing the number of administration staff, reorganization of ministries, reducing operating costs, and subsidies. Even grants of the local government have been affected by this policy in order to leave more space to investments. So an improved cost structure and quality of their addressing.

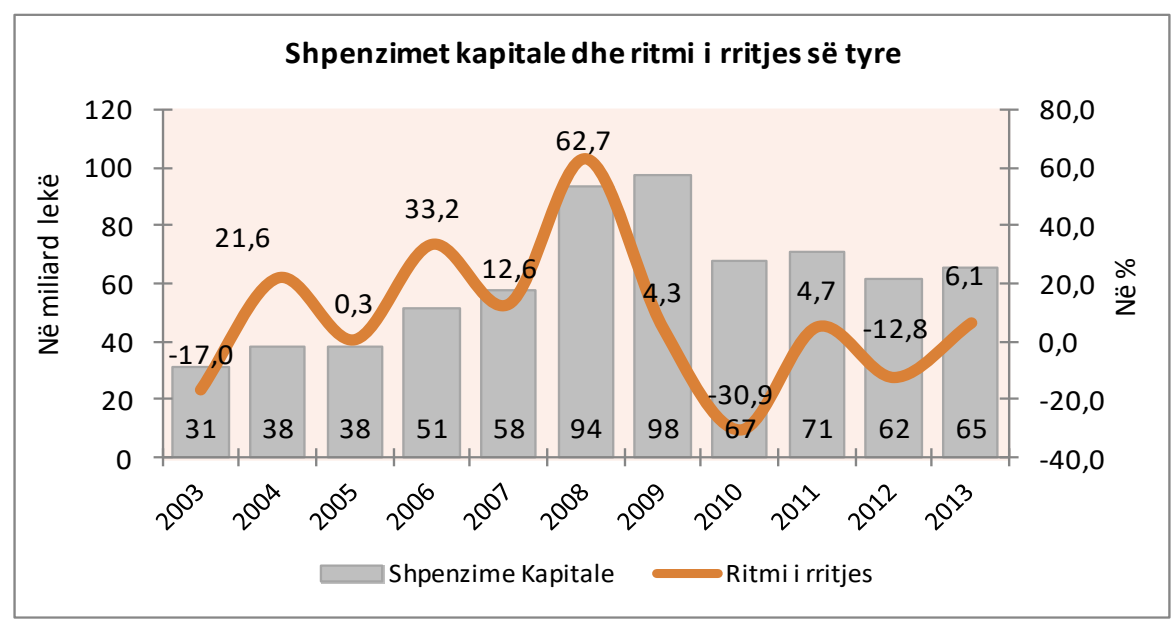

Graph 6.Capital expenses and their growth rate.

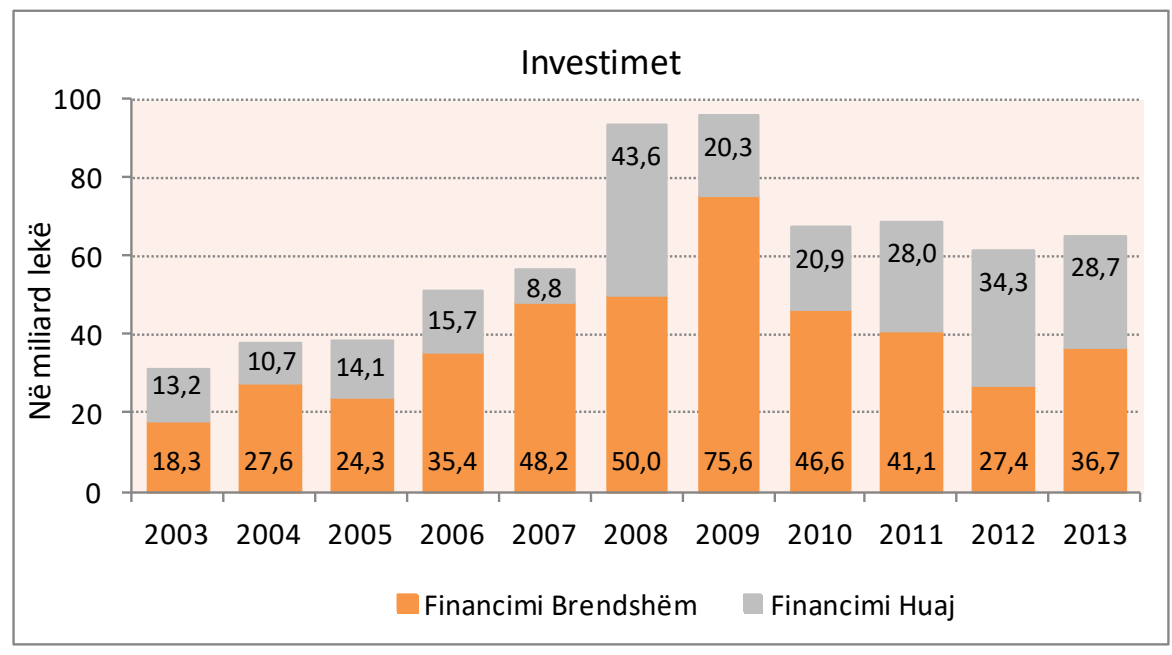

Graph 7. Investments (internal and foreign funding). 


\section{Conclusions and recommendations}

Is the government able to increase investment capacity through expenditures, without negatively affecting the economy? This is one of the central questions which of the theory of public finance nowadays and political debate in Albania. A positive answer to that question is yet more difficult in the case of our country taking into account elements such as the prolonged transition, the problems in the functioning of market institutions, the fragility of macroeconomic variables, gaps in coordination of strategies, etc. However, according to theoretical views, empirical studies, and practical facts the position and role of the state in transition economies is considered very essential in accelerating the economy. In addition to other factors such as the initial conditions, the problems inherited from the past, the level of incomes per capita, the presence of the private sector, etc. the method of implementation of the political system, the construction method, monitoring of public institutions, and the continuity and political will to implement the reforms are elements that indicate that the government of a country in transition is functioning optimally to promote a sustainable economic development. Other elements which show the same thing are the greater involvement of civil society in decision making, the increasing of public support, the strict controls of corruption, private interests capturing the state and the rigorous enforcement of the law.

One of the challenges which the fiscal policy in Albania has faced is its contribution in stabilization. Fiscal consolidation through the establishment of a balance between reducing the deficit, the public debt and the need to carry out necessary capital investments, had a positive impact in terms of stability and in terms of economic growth. The revenue policy has improved in terms of tax rates by adjusting them with tax advanced models. Reforms in revenue administration have also contributed positively, but collection levels still leave to be desired. Even expenses have their own problems in addition to sustainability, which has been periodic. Addressing expenditures against priority sectors is an important issue but not the only one. The way they are used and where they are addressed mostly towards capital investments or current expenditure is quite difficult to judge. The government should be able to limit the level of available expenditures in order to use them in the most efficient manner possible. It would be very appropriate for Albania to undertake fiscal reform in consultation with international organizations in order not to enter into a public finance crisis in conditions when even other circumstances are not favorable.

\section{BIBLIOGRAPHY}

[1] Assaf Razin and Sadka Efraim . (1991). Efficient investment in the presence of capital flight. Journal of International economies Vol 31 Issues 1-2, 171-181.

[2] Boadway R., E. Chamberlain and C. Emmerson . (2009). Taxation of Wealth and Wealth Transfers in The Mirrlees Review: Dimensions of Tax Design, S. Adam, T. Besley and R. Blundell. Oxford University Press .

[3] Crawford I, M. Keen and S. Smith. (2009). Value added tax and excises in The Mirrlees Review: Dimensions of Tax Design. The Mirrlees Review: Dimensions of Tax Design , 275.

[4] Cremer H. and P. Pestieau. (2003). Wealth Transfer Taxation: A Survey. CESifo Group Munich , 1061.

[5] D.Myles, G. (2009). Economic Growth and the Role of Taxation-Theory. OECD , 48.

[6] James A.Richardson and W.Bartley Hildreth. (1999). Handbook on Taxation. Basel: Marcel Dekker Inc.

[7] Koester B.Reinhard dhe Roger C.Kormendi. (1988). Taxation Aggregate Activity and Economic Growth; Cross Country Evidence on Some-Side Hypotheses". Economic Inguiry .

[8] Prammer, D. (2011). QUALITY OF TAXATION AND THE CRISIS: TAX SHIFTS FROM A GROWTH PERSPECTIVE. Luxembourg: European Union.

[9] Ramsey. (1927). A Contribution to the Theory of Taxation. The economic Journal , 47-61.

[10] Robert J.Barro and Xavier Sala-iMartin. (1999). Economic growth. New York: The MIT Press.

[11] Szostak, R. (2009). The Causes of Economic Growth. Interdisciplinary Perspectives. Berlin: Springer.

[12] Tiebout, C. M. (1956, October). A Pure Theory of Local Expenditures. The Journal of Political Economy, Vol. 64, No. 5 , p. 416-424. 